\title{
Relationship between progeny growth performance and molecular marker-based genetic distances in Eucommia ulmoides parental genotypes
}

\author{
Y. Li, Y.C. Wei, Z.Q. Li, S.H. Wang and L. Chang \\ College of Forestry, Northwest A\&F University, Yangling, Shaanxi, China \\ Corresponding author: Z.Q. Li \\ E-mail: lizhouqi@nwsuaf.edu.cn
}

Genet. Mol. Res. 13 (3): 4736-4746 (2014)

Received June 14, 2013

Accepted October 30, 2013

Published July 2, 2014

DOI http://dx.doi.org/10.4238/2014.July.2.3

\begin{abstract}
Progeny performances, variations and combining abilities for growth traits were evaluated in a factorial mating design of Eucommia ulmoides. Three marker systems, sequence-related amplified polymorphism, amplified fragment length polymorphism, and intersimple sequence repeat, were used to determine genetic distances between parents. Correlations of genetic distances with progeny performances, within-family coefficients of variation and specificcombining abilities were established for height and basal diameter traits. Significant positive correlations were found between progeny performances of growth traits and genetic distances of parents based on sequence-related amplified polymorphism markers or a combination of all 3 marker systems. This revealed that crosses between genetically distant parents produced progenies with excellent growth performances. The lack of correlations between parental genetic distances and withinfamily coefficients of variation or specific-combining abilities suggested that these characteristics were unpredictable. The results of this study
\end{abstract}


represent a potential criterion to predict progeny performances and choose parents in the breeding program.

Key words: Eucommia ulmoides; Progeny performance; Specific-combining abilities; Genetic distance

\section{INTRODUCTION}

Eucommia ulmoides Oliv., whose bark and leaves have been proven to possess medicinal activity, is one of the unique commercial tree species in China. Historically, only the bark was officially recognized as a traditional Chinese tonic drug. However, modern scientific research has reported that chemical constituents in the leaves of E. ulmoides are similar to those in the bark, and the pharmaceutical effects are also similar (Takamura et al., 2007). These constituents have high pharmacological activities and health care functions, such as lowering blood pressure (Kwan et al., 2004) and sugar (Lee et al., 2005), antioxidant (Hsieh and Yen, 2000), and anti-mutation (Nakamura et al., 1997). Eucommia rubber, obtained from the seeds, bark, and leaves, is a hard rubber with thermoplasticity, and it has properties that are similar to those of plastic (Nakazawa et al., 2009). The E. ulmoides male flower is abundant in bioactive constituents, and it is suitable to be developed as a health-care flower tea (Dong et al., 2012). Currently, E. ulmoides is widely cultivated in low mountains and hills of central China and has been introduced to other parts of the world, such as Russia, Japan, Korea, Europe, and America.

Because the prospects of exploitation and utilization are very extensive, E. ulmoides breeding programs have been carried out to select excellent clones from different parts of China (Zhang et al., 2004). Genetic improvement strategies for E. ulmoides should include crosses between divergent clones and progeny breeding to achieve the largest gains per unit effort, but it is an expensive and time-consuming endeavor. Moreover, with respect to forest trees, delays before assessing individual performances are long, and a strategy for predicting heterosis before making the crosses and thereby reducing the number of combinations to be tested would be particularly desirable. Many observations and studies consistently provided evidence that there is a correlation between the genetic distance of parents and progeny performance or heterosis for most crops (Zhang et al., 1996, 2007; Hale et al., 2007; Devi and Singh, 2011; Benin et al., 2012) and several forest trees (Vaillancourt et al., 1995; Kopp et al., 2002; Dias et al., 2003). In these studies, genetic distances were estimated by molecular markers involving restriction fragment length polymorphism, random amplified polymorphic DNA, simple sequence repeat, amplified fragment length polymorphism (AFLP), sequence-related amplified polymorphism (SRAP), and inter-simple sequence repeat (ISSR). The correlation between the genetic distance of parents and progeny performance suggests a potential prediction of heterosis and selection of parents.

Our goal in this study was to investigate the relationships between genetic distances of the parents and progeny performances, variations or specific-combining abilities (SCA). The different steps of the study were: 1) to assess progeny performances, variations and combining abilities based on a factorial mating design; 2) to estimate genetic distances of the parents using SRAP, AFLP, and ISSR markers; and 3) to study the relationships between genetic distances and growth performance, variations or SCA of the progenies. It is expected that marker-based genetic distance may be utilized as a guide to predict progeny performances and choose parents in the breeding program. 


\section{MATERIAL AND METHODS}

\section{Plant materials and field experiments}

The plant materials of this study consisted of a factorial mating design involving 5 clones as female parents and 5 clones as male parents (Table 1). All parents were produced by researchers through controlled breeding of clones collected from different parts of China (Zhang et al., 2004). Eight clones were planted in the village of Yantuo, Lingbao, Henan Province, and 2 clones (Qinzhong No. 1 and Qinzhong No. 2) were planted in the museum garden of Northwest A\&F University. Controlled pollination was performed in the village of Yantuo in April 2009, and seeds were collected in October and stored at $4^{\circ} \mathrm{C}$. Seeds were sown in germination cups in March 2010, and seedlings were transplanted to a greenhouse until the next spring. Unfortunately, technical problems in the controlled pollination and planting prevented the mating design from being complete and balanced, and 24 families survived except the family of Yanci x Longguai (Table 2). Field experiments were carried out in the nursery of Northwest A\&F University in March 2011, and a complete randomized block design was used with 3 replications and 20-tree plots. Height and basal diameter of the seedlings were measured in October 2011 after approximately 7 months of growth.

Table 1. List of Eucommia ulmoides genotypes used in the factorial mating design.

\begin{tabular}{rllll}
\hline No. & Genotypes & Sex & Source & Special characters \\
\hline 1 & Xiaoye & Female & Luoyang, Henan & Leaf oval oblong, small and dense, bark smooth. \\
2 & Daye & Female & Lingbao, Henan & Leaf ovate and large, bark smooth. \\
3 & Daguo & Female & Lingbao, Henan & Leaf oval oblong, bark smooth, fruit large. \\
4 & Yanci & Female & Lingbao, Henan & Leaf oval oblong, bark smooth, high yield of fruit \\
5 & Huazhong No. 2 & Female & Luoyang, Henan & Leaf ovate, bark rough, cultivar, high yield, high resistance to diseases and insect pests. \\
6 & Qinzhong No. 1 & Male & Lueyang, Shaanxi & Leaf oval oblong, bark rough, cultivar, high content of bioactive constituents and eucommia rubber. \\
7 & Qinzhong No .2 & Male & Cili, Hunan & Leaf oval oblong, bark smooth, cultivar, high content of bioactive constituents and eucommia rubber. \\
8 & Luochao No. 3 & Male & Luoyang, Henan & Leaf oval oblong, bark smooth. \\
9 & Ziye & Male & Cili, Hunan & Leaf ovate and purple, bark smooth, ornamental tree. \\
10 & Longguai & Male & Luoyang, Henan & Leaf ovate, bark smooth, branch dragon shape, ornamental tree \\
\hline
\end{tabular}

\section{SRAP, AFLP and ISSR markers}

Genomic DNA was extracted from leaves of the parental trees by a modified cetyltrimethylammonium bromide procedure (Porebski et al. 1997). Three marker systems, SRAP (10 primer combinations), AFLP (10 primer combinations), and ISSR (10 primers), were used to determine genetic distances between parents. The SRAP reactions ( $25 \mu \mathrm{L}$ final volume) contained $30 \mathrm{ng}$ DNA, $2.5 \mathrm{mM} \mathrm{Mg}^{2+}, 0.2 \mathrm{mM}$ dNTPs, $1.5 \mathrm{U}$ Taq DNA polymerase, $0.4 \mu \mathrm{M}$ forward primer, $0.4 \mu \mathrm{M}$ reverse primer, and $1 \mathrm{X}$ polymerase chain reaction buffer, and the amplification program was carried out as described by Li and Quiros (2001). The AFLP and ISSR reactions were performed according to the protocols of Wang et al. (2011) and Wu et al. (2011), respectively. Amplification products were separated on 6\% polyacrylamide gels and visualized by silver nitrate staining.

\section{Data analyses}

The presence and absence of DNA fragments were recorded for each parent, and the 
genetic similarity Sij between parents was calculated in NTSYS-PC version 2.1 (Rohlf, 1998) using Nei and Li's statistics (Nei and Li, 1979):

$$
S i j=2 N i j /(N i+N j)
$$

(Equation 1)

where $N i j$ is the number of DNA fragments shared by both parents $i$ and $j, N i$ is the total number of DNA fragments presented by parent $i$, and $N j$ is the total number of DNA fragments presented by parent $j$. Similarity matrices were transformed to genetic dissimilarity matrices according to the following equation:

$$
D i j=1-S i j
$$

where $D i j$ is the genetic distance between each parental pair $i$ and $j$. Progeny performances, variations, general-combining abilities (GCA), and SCA were investigated for height and basal diameter according to the methods of Wei et al. (2012). Correlations between the genetic distances of the respective parents and progeny performances, within-family coefficients of variation and SCA were calculated for each quantitative trait. The statistics was carried out using SPSS (Statistical Product and Service Solutions) 13.0 for Windows.

\section{RESULTS}

\section{Progeny performances, variances, and combining abilities}

Analyses of variance indicated that highly significant phenotypic variations $(\mathrm{P}<0.01)$ among the 24 families were found for the height and basal diameter traits. The average height was $111.995 \mathrm{~cm}$, with full-sib family means that ranged from 90.235 (family Huazhong No. $2 \mathrm{x}$ Ziye) to $141.363 \mathrm{~cm}$ (family Xiaoye x Qinzhong No. 1), and within-family coefficients of variation that varied from 18.009 (family Daguo x Longguai) to $38.341 \%$ (family Daguo $\mathrm{x}$ Qinzhong No. 2) (Table 2). The basal diameters ranged from 8.463 (family Daguo x Qinzhong No. 1) to $12.496 \mathrm{~mm}$ (family Xiaoye $\mathrm{x}$ Qinzhong No. 1), with an average of $10.906 \mathrm{~mm}$, and family coefficients of variation varied from 6.925 (family Daguo x Qinzhong No. 1) to $25.531 \%$ (family Daguo x Qinzhong No. 2) (Table 2). The high amount of variability offered an opportunity to select for superior individuals within families.

The pooled analysis exhibited significant variance $(\mathrm{P}<0.05)$ for the female GCA to height and highly significant variance $(\mathrm{P}<0.01)$ for diallel set effects to basal diameter. Female Xiaoye and male Qinzhong No. 1 were found to be good general parents while the cross Huazhong No. 2 x Qinzhong No. 1 was identified as a good specific combination with the highest SCA effects both in height (11.105) and basal diameter (13.500) (Table 2). Other good parental combinations were Daye x Ziye, Daguo x Luochao No. 3, Daguo x Longguai and Xiaoye x Qinzhong No. 2 (Table 2). An SCA with a higher magnitude than that of GCA indicated that non-additive gene action had a crucial effect in determining the height and basal diameter traits.

\section{Marker polymorphisms and genetic distances}

The 10 parental lines were surveyed with 3 different marker systems: SRAP, AFLP and ISSR. Ten SRAP primers generated 235 amplified products, of which 209 DNA fragments 
were polymorphic with an average of 20.9 polymorphic DNA fragments per primer. The polymorphic ratio was $88.94 \%$. In the case of the AFLP markers, 10 primers generated 192 amplified products, of which 123 DNA fragments were polymorphic with an average of 12.3 polymorphic DNA fragments per primer. The polymorphic ratio was $64.06 \%$. For ISSR markers, 10 primers generated 147 amplified products, of which 129 DNA fragments were polymorphic with an average of 12.9 polymorphic DNA fragments per primer. The polymorphic ratio was $87.76 \%$. The maximum number of DNA fragments was produced by the SRAP primer MeACC/ EmCAA, for which all 45 DNA fragments that were produced were polymorphic.

\begin{tabular}{|c|c|c|c|c|c|c|}
\hline \multirow{2}{*}{ Female } & \multicolumn{5}{|c|}{ Male } & \multirow[t]{2}{*}{ Female GCA } \\
\hline & Qinzhong No. 1 & Qinzhong No. 2 & Luochao No. 3 & Ziye & Longguai & \\
\hline \multirow{2}{*}{\multicolumn{7}{|c|}{ Xiaoye }} \\
\hline & & & & & & \\
\hline M & 141.363 & 134.167 & 119.577 & 120.291 & 119.604 & \\
\hline $\mathrm{CV}$ & 25.746 & 22.463 & 29.179 & 26.521 & 23.759 & \\
\hline SCA & 5.326 & 5.391 & -3.666 & -3.339 & -2.991 & 13.483 \\
\hline \multicolumn{7}{|l|}{$\mathrm{D}$} \\
\hline M & 12.496 & 12.171 & 11.443 & 10.907 & 11.550 & \\
\hline $\mathrm{CV}$ & 21.763 & 17.998 & 25.172 & 18.592 & 19.010 & \\
\hline SCA & 4.687 & 6.041 & -4.174 & -3.300 & -3.502 & 9.275 \\
\hline $\mathrm{N}$ & 60 & 60 & 55 & 60 & 60 & (2) \\
\hline \multicolumn{7}{|l|}{ Daye } \\
\hline \multicolumn{7}{|l|}{$\mathrm{H}$} \\
\hline M & 113.016 & 92.011 & 101.415 & 112.022 & 96.941 & \\
\hline $\mathrm{CV}$ & 31.116 & 31.391 & 27.723 & 25.930 & 30.676 & \\
\hline \multirow{2}{*}{\multicolumn{7}{|c|}{$\mathrm{D}$}} \\
\hline & & & & & & \\
\hline $\begin{array}{l}\mathrm{M} \\
\mathrm{CV}\end{array}$ & $\begin{array}{l}10.875 \\
17374\end{array}$ & $\begin{array}{l}10.044 \\
18.957\end{array}$ & $\begin{array}{l}10.763 \\
19660\end{array}$ & $\begin{array}{l}10.717 \\
16362\end{array}$ & $\begin{array}{l}10.882 \\
19348\end{array}$ & \\
\hline $\begin{array}{l}\text { CV } \\
\text { SCA }\end{array}$ & $\begin{array}{l}17.374 \\
-0.186\end{array}$ & $\begin{array}{l}18.957 \\
-8.914\end{array}$ & $\begin{array}{r}19.660 \\
3.514\end{array}$ & $\begin{array}{r}16.362 \\
6.487\end{array}$ & $\begin{array}{l}19.348 \\
-1.142\end{array}$ & -5.562 \\
\hline $\mathrm{N}$ & 60 & 60 & 60 & 49 & 38 & 5.002 \\
\hline \multicolumn{7}{|l|}{ Daguo } \\
\hline \multicolumn{7}{|l|}{$\mathrm{H}$} \\
\hline $\mathrm{M}$ & 97.750 & 111.111 & 113.214 & 108.834 & 110.500 & \\
\hline $\mathrm{CV}$ & 27.984 & 38.341 & 21.338 & 29.915 & 18.009 & \\
\hline \multirow{2}{*}{\multicolumn{7}{|c|}{$\mathrm{D}^{\mathrm{NCA}}$}} \\
\hline & & & & & & \\
\hline M & 8.463 & 11.089 & 11.330 & 11.557 & 11.040 & \\
\hline $\mathrm{CV}$ & 6.925 & 25.531 & 11.364 & 18.803 & 18.455 & \\
\hline SCA & -19.542 & 0.042 & 6.081 & 5.831 & 7.360 & -0.402 \\
\hline $\mathrm{N}$ & 34 & 39 & 34 & 32 & 38 & \\
\hline \multirow{2}{*}{\multicolumn{7}{|c|}{ Yanci }} \\
\hline & & & & & & $\mathrm{H}$ \\
\hline & 121.527 & 113.947 & 101.000 & 112.983 & & \\
\hline $\mathrm{CV}$ & 24.977 & 23.432 & 33.685 & 27.273 & & \\
\hline \multirow{2}{*}{\multicolumn{7}{|c|}{$\mathrm{D}^{\text {SCA }}$}} \\
\hline & & & & & & \\
\hline M & 11.030 & 10.774 & 10.003 & 10.879 & & \\
\hline $\mathrm{CV}$ & 17.423 & 17.429 & 21.579 & 18.291 & & \\
\hline SCA & 1.610 & 1.124 & -7.576 & 5.810 & & -0.363 \\
\hline $\mathrm{N}$ & 58 & 38 & 38 & 60 & & \\
\hline \multicolumn{7}{|c|}{ Huazhong No. 2} \\
\hline \multicolumn{7}{|c|}{$\mathrm{H}$} \\
\hline M & 130.200 & 113.807 & 107.868 & 90.235 & 104.491 & \\
\hline $\mathrm{CV}$ & 28.125 & 24.967 & 29.072 & 32.017 & 24.756 & \\
\hline \multirow{2}{*}{\multicolumn{7}{|c|}{$D^{\mathrm{SCA}}$}} \\
\hline & & & & & & \\
\hline M & 11.867 & 11.261 & 10.791 & 9.124 & 10.692 & \\
\hline $\mathrm{CV}$ & $\begin{array}{l}15.773 \\
500\end{array}$ & 19.169 & 19.120 & 22.504 & 19.495 & \\
\hline $\mathrm{N}_{\mathrm{N}}^{\text {SCA }}$ & 13.500 & 1.779 & 2.241 & -14.752 & -3.010 & -3.043 \\
\hline$\stackrel{\mathrm{N}}{\text { Male GC }}$ & 40 & 35 & 60 & 40 & 60 & \\
\hline \multicolumn{7}{|c|}{ Male GCA } \\
\hline $\begin{array}{l}\mathrm{H} \\
\mathrm{D}\end{array}$ & $\begin{array}{r}7.596 \\
13.500\end{array}$ & $\begin{array}{l}0.998 \\
1.782\end{array}$ & $\begin{array}{r}-3.084 \\
2.244\end{array}$ & $\begin{array}{r}-2.631 \\
-14.748\end{array}$ & $\begin{array}{l}-3.600 \\
-3.011\end{array}$ & \\
\hline
\end{tabular}


Genetic distances based on 209 SRAP markers $\left(\mathrm{GD}_{\text {srap }}\right)$, 123 AFLP markers $\left(\mathrm{GD}_{\text {aftp }}\right)$, 129 ISSR markers $\left(\mathrm{GD}_{\text {isst }}\right)$ and all of the 461 markers $\left(\mathrm{GD}_{\text {total }}\right)$ were computed (Table 3$)$. $\mathrm{GD}_{\text {srap }}$ ranged from 0.206 to 0.359 , with an average of 0.269 ; $\mathrm{GD}_{\text {affp }}$ ranged from 0.252 to 0.500 , with an average of $0.347 ; \mathrm{GD}_{\text {issr }}$ ranged from 0.240 to 0.442 , with an average of 0.346 ; and $\mathrm{GD}_{\text {total }}$ ranged from 0.234 to 0.377 , with an average of 0.311 . No significant correlation among these GDs was observed.

\begin{tabular}{|c|c|c|c|c|c|}
\hline \multirow[t]{2}{*}{ Female } & \multicolumn{5}{|c|}{ Male } \\
\hline & Qinzhong No. 1 & Qinzhong No. 2 & Luochao No. 3 & Ziye & Longguai \\
\hline \multicolumn{6}{|l|}{ Xiaoye } \\
\hline $\mathrm{GD}_{\text {san }}$ & 0.335 & 0.325 & 0.354 & 0.349 & 0.359 \\
\hline $\mathrm{GD}$ & 0.500 & 0.276 & 0.350 & 0.333 & 0.325 \\
\hline $\mathrm{GD}^{\text {alfp }}$ & 0.333 & 0.442 & 0.426 & 0.388 & 0.426 \\
\hline $\mathrm{GD}_{\text {isst }}$ & 0.377 & 0.345 & 0.373 & 0.356 & 0.369 \\
\hline \multicolumn{6}{|l|}{ Daye } \\
\hline $\mathrm{GD}$ & 0.301 & 0.215 & 0.225 & 0.249 & 0.297 \\
\hline $\mathrm{GD}_{\text {sap }}$ & 0.447 & 0.309 & 0.317 & 0.415 & 0.390 \\
\hline $\mathrm{GD}_{\mathrm{i} i \mathrm{ssc}}$ & 0.372 & 0.434 & 0.341 & 0.318 & 0.264 \\
\hline $\mathrm{GD}^{\text {isst }}$ & 0.360 & 0.302 & 0.282 & 0.312 & 0.312 \\
\hline \multicolumn{6}{|l|}{$\begin{array}{l}\text { UD total } \\
\text { Daguo }\end{array}$} \\
\hline $\mathrm{GD}_{\text {san }}$ & 0.225 & 0.244 & 0.234 & 0.306 & 0.220 \\
\hline $\mathrm{GD}^{2}$ & 0.350 & 0.341 & 0.252 & 0.415 & 0.407 \\
\hline $\mathrm{GD}_{\text {isst }}^{\text {alst }}$ & 0.411 & 0.349 & 0.302 & 0.326 & 0.318 \\
\hline $\mathrm{GD}^{\text {iss }} \mathrm{stal}_{\text {tat }}$ & 0.310 & 0.299 & 0.258 & 0.341 & 0.297 \\
\hline \multicolumn{6}{|l|}{ Yanci } \\
\hline $\mathrm{GD}_{\text {san }}$ & 0.258 & 0.278 & 0.297 & 0.206 & \\
\hline $\mathrm{GD}^{\mathrm{s} \text { sap }}$ & 0.374 & 0.285 & 0.276 & 0.276 & \\
\hline GD & 0.419 & 0.357 & 0.279 & 0.240 & \\
\hline $\mathrm{GD}^{\mathrm{iss}}$ & 0.334 & 0.302 & 0.286 & 0.234 & \\
\hline \multicolumn{6}{|c|}{$\begin{array}{l}\text { Huazhol } \\
\text { Hual }\end{array}$} \\
\hline $\mathrm{GD}$ & 0.211 & 0.268 & 0.220 & 0.263 & 0.215 \\
\hline $\mathrm{GD}_{\text {stap }}$ & 0.415 & 0.309 & 0.268 & 0.366 & 0.325 \\
\hline $\mathrm{GD}_{\mathrm{afp}}$ & 0.380 & 0.364 & 0.256 & 0.248 & 0.302 \\
\hline $\mathrm{GD}_{\text {totial }}$ & 0.312 & 0.306 & 0.243 & 0.286 & 0.269 \\
\hline
\end{tabular}

\section{Relationships between genetic distance and progeny performance, within-family variability, and SCA}

$\mathrm{GD}_{\text {srap }}, \mathrm{GD}_{\text {affp }}, \mathrm{GD}_{\text {issr }}$, and $\mathrm{GD}_{\text {total }}$ were used for correlation analysis with progeny growth performances (family means), within-family coefficients of variation, and SCA (Table 4). Significant correlation coefficients were detected between progeny growth performances and $\mathrm{GD}_{\text {srap }}$ (Figure 1) and between progeny growth performances and $\mathrm{GD}_{\text {total }}$ (Figure 2). However, $\mathrm{GD}_{\text {affp }}$ and $\mathrm{GD}_{\text {issr }}$ showed no significant correlations with progeny growth performances, except for $\mathrm{GD}_{\text {issr }}$ with height trait. All of the other correlations, including those between genetic distances and within-family coefficient of variation or SCA, were low and non-significant. When individual marker systems were used to estimate genetic distances, the SRAP-based genetic distances were always more highly correlated with height and basal diameter than AFLP- and ISSR-based genetic distances. Regardless of the traits, genetic distances based on the combination of all 3 marker systems had a higher correlation with progeny growth performances than genetic distances based on any single marker system. 
Table 4. Correlation coefficients (probability values in parentheses) of genetic distances with hybrid performances (family means, M), coefficients of variation (CV), and specific-combining abilities (SCA).

\begin{tabular}{|c|c|c|c|c|c|c|}
\hline \multirow[t]{2}{*}{ Genetic distances } & \multicolumn{3}{|c|}{ Height } & \multicolumn{3}{|c|}{ Basal diameter } \\
\hline & $M$ & $\mathrm{CV}$ & SCA & $\mathrm{M}$ & $\mathrm{CV}$ & $\mathrm{SCA}$ \\
\hline $\mathrm{GD}_{\text {srap }}$ & $\begin{array}{c}0.425^{*} \\
(0.019)\end{array}$ & $\begin{array}{c}0.002 \\
(0.496)\end{array}$ & $\begin{array}{l}-0.068 \\
(0.376)\end{array}$ & $\begin{array}{c}0.386^{*} \\
(0.031)\end{array}$ & $\begin{array}{c}0.344 \\
(0.050)\end{array}$ & $\begin{array}{l}-0.101 \\
(0.319)\end{array}$ \\
\hline $\mathrm{GD}_{\mathrm{affp}}$ & $\begin{array}{c}0.260 \\
(0.110)\end{array}$ & $\begin{array}{c}0.077 \\
(0.361)\end{array}$ & $\begin{array}{c}0.201 \\
(0.173)\end{array}$ & $\begin{array}{c}0.213 \\
(0.159)\end{array}$ & $\begin{array}{c}0.092 \\
(0.334)\end{array}$ & $\begin{array}{c}0.163 \\
(0.223)\end{array}$ \\
\hline $\mathrm{GD}_{\text {issr }}$ & $\begin{array}{c}0.381^{*} \\
(0.033)\end{array}$ & $\begin{array}{l}-0.161 \\
(0.226)\end{array}$ & $\begin{array}{l}-0.111 \\
(0.302)\end{array}$ & $\begin{array}{c}0.191 \\
(0.186)\end{array}$ & $\begin{array}{l}-0.143 \\
(0.253)\end{array}$ & $\begin{array}{l}-0.104 \\
(0.314)\end{array}$ \\
\hline $\mathrm{GD}_{\text {total }}$ & $\begin{array}{c}0.521^{* * *} \\
(0.005)\end{array}$ & $\begin{array}{l}-0.037 \\
(0.432)\end{array}$ & $\begin{array}{l}-0.003 \\
(0.495)\end{array}$ & $\begin{array}{c}0.394^{*} \\
(0.028)\end{array}$ & $\begin{array}{c}0.173 \\
(0.210)\end{array}$ & $\begin{array}{l}-0.034 \\
(0.436)\end{array}$ \\
\hline
\end{tabular}

*,**Significant at $\mathrm{P}=0.05$ and $\mathrm{P}=0.01$, respectively.

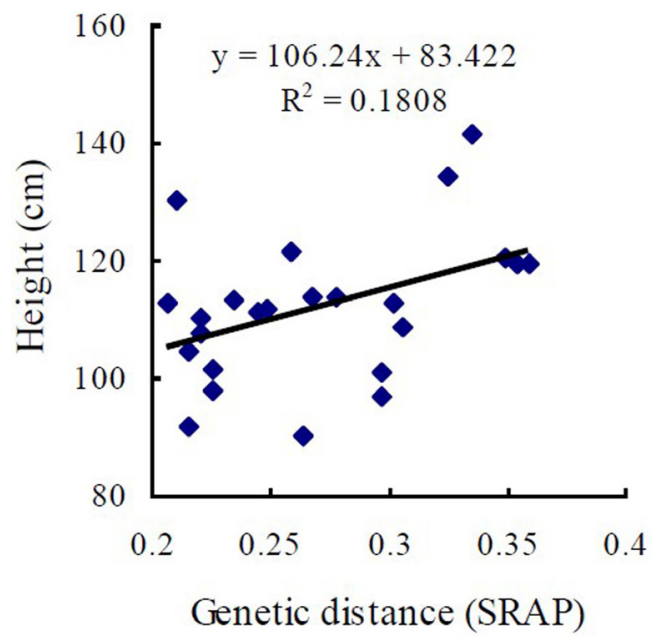

Figure 1. Correlation between height and $\mathrm{GD}_{\text {srap }}$.

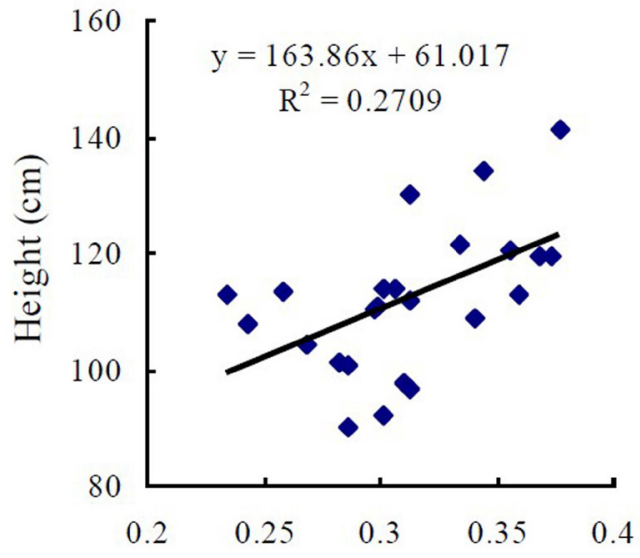

Genetic distance (total)

Figure 2. Correlation between height and $\mathrm{GD}_{\text {total }}$. 


\section{DISCUSSION}

We revealed a significant positive correlation between genetic distances of parents based on SRAP markers or a combination of all 3 marker systems and performances of the progenies with respect to the height and basal diameter growth characteristics. The two traits were highly correlated. This suggests that high levels of heterozygosity provide advantages to progeny trees for growth characteristics. A similar result was reported by Dias et al. (2003), who observed a significant positive correlation between the genetic distances of parents and performances of the progenies for yield traits in cacao. Moreover, significant correlations of a quadratic equation between the genetic distance of parents and height or basal diameter were established in Liriodendron (Li and Wang, 2002) and poplar (Li et al., 2008).

Nevertheless, the parental genetic distance often failed to predict progeny performance. A decrease in the progeny performance was usually observed when crosses involved generally related parents, but only a slight increase in progeny performance was obtained when the genetic distance between the parents increased. For crop species, the predictive value of the genetic distance based on molecular markers is often restricted to crosses between parents from the same heterotic group and is not extended to crosses between different heterotic groups (Zhang et al., 1996; Devi and Singh, 2011). In studies involving forest trees, a lack of association between genetic distance and various traits has generally been observed in Eucalyptus (Vaillancourt et al., 1995; Baril et al., 1997) and Salix (Kopp et al., 2002); this also holds for our study in E. ulmoides when the genetic distance was calculated by AFLP and ISSR markers.

Conflicting results could be a reflection of the different marker systems that were used and the rate of genome coverage. Yu et al. (2005) pointed out that many DNA markers were located in non-expressed regions or had little or no association with agronomically important traits and heterosis. Markers such as SRAPs were generally more tightly linked to expressed regions of the genome than markers such as AFLPs and ISSRs. Thus, they could presumably more accurately represent areas contributing to heterosis. In this study, when genetic distances were based on individual marker systems, their associations with progeny performances were less pronounced than when using a combination of marker systems. Genetic distances based on AFLPs and ISSRs were not as highly correlated with progeny performances as SRAP-based genetic distances. This is probably because of the low number of AFLP and ISSR markers used in this study and the lack of adequate genome coverage by these markers.

Estimates of genetic distances between the parental genotypes based on unselected DNA markers alone were not promising for predicting performance (Jaikishan et al., 2010), and 10 "key" informative expressed sequence tag-SSR markers that showed a higher positive correlation with grain yield heterosis were recommended to predict heterosis in rice breeding programs. These findings were in agreement with theoretical results of Charcosset and Essioux (1994), who attributed the low correlation between heterosis and genetic distance to no or only loose linkage of heterosis-affecting quantitative trait loci (QTL) to the molecular markers employed in estimating genetic distance. Effective prediction of progeny performance using molecular marker as suggested by Bernardo (1992) would be feasible only when a significant portion (30-50\%) of the selected markers are linked with QTLs. In this present study, we found that the correlation coefficient between $\mathrm{GD}_{\text {srap }}$ and height $(0.425)$ indicated a moderately strong relationship (Figure 1), so it is possible that some of the SRAP markers might be linked to QTLs for height. It is expected that this correlation might increase by add- 
ing more SRAP marker loci in the screening, which will increase the chance of association with additional QTLs.

Besides DNA markers, the prediction effect was affected by many other factors. First, the materials used to produce cross-combinations affected the prediction. Increasing the number of parental genotypes analyzed resulted in a significant relationship between the parental genetic distance and progeny performance in poplar (Li et al., 2008). Second, the prediction effect varied with the traits, and the prediction effects of the traits with high heredity power were better than those of the traits with lower heredity power (Manjarrez-Sandoval et al., 1997). For example, predictions of the basal diameter are more difficult than those of the height in this study. Third, most important traits of crops and trees are quantitative traits that are controlled by more genes and are easily affected by the environment; therefore, predictions of these traits might not be very effective.

No significant correlation between the genetic distance and SCA was noticed. This may simply be because the dominance variation for early growth was just too small in this factorial, which may change with age (Vaillancourt et al., 1995). An SCA value with a higher magnitude than that of GCA confirmed breeding strategies in E. ulmoides that select primarily based on SCA to obtain more genetic gain in growth traits. Thus, confidence in the prediction

of progeny growth performances using $\mathrm{GD}_{\text {srap }}$ and $\mathrm{GD}_{\text {total }}$ must be tempered because of the low correlation between genetic distance and SCA.

No significant correlation could be established between the genetic distance and within-family coefficient of variation. Speculatively, limitations in the experimental design, especially the small number of progeny per family, and differing numbers of progeny per family may have influenced the observed variability. The variability in height and basal diameter growth was not uniform across families in this study, and the observed variability appears to be due, at least in part, to genetic causes. This offered an opportunity to select within families for superior individuals that far exceed the mean family performance. However, genetic distances appeared to have little value in selecting parents whose progeny will be highly variable in the breeding program.

The relationships between genetic distances and progeny performances are complex because of the complexity of the genetic basis of heterosis (Zhang et al., 1996). Fortunately, we have shown a significant and positive correlation between the genetic distance of the parents and growth performance of the progeny. This result represents a potential selection criterion in the breeding program if growth is the requested characteristic. Crosses should then be carried out between parents with a maximal genetic distance. Concerning other traits such as bioactive constituents and Eucommia rubber, investigations should focus on the identification of markers linked to QTLs involved in the expression of the characteristic that could lead to a marker-assisted selection scheme in E. ulmoides breeding programs.

\section{ACKNOWLEDGMENTS}

Research supported by the Special Fund for Forestry Scientific Research in the Public Interest of China (\#201204605).

\section{REFERENCES}

Baril CP, Verhaegen D, Vigneron Ph, Bouvet JM, et al. (1997). Structure of specific combining ability between two 
species of Eucalyptus 1. RAPD data. Theor. Appl. Genet. 94: 796-803.

Benin G, Matei G, Costa de OA, Silva GO, et al. (2012). Relationships between four measures of genetic distance and breeding behavior in spring wheat. Genet. Mol. Res. 11: 2390-2400.

Bernardo R (1992). Relationship between single-cross performance and molecular marker heterozygosity. Theor. Appl. Genet. 83: 628-634.

Charcosset A and Essioux L (1994). The effect of population structure on the relationship between heterosis and heterozygosity at marker loci. Theor. Appl. Genet. 89: 336-343.

Devi P and Singh NK (2011). Heterosis, molecular diversity, combining ability and their interrelationships in short duration maize (Zea mays L.) across the environments. Euphytica 178: 71-81.

Dias LADS, Marita J, Cruz CD, Barros EGD, et al. (2003). Genetic distance and its association with heterosis in cacao. Braz. Arch. Biol. Technol. 46: 339-347.

Dong J, Ma XH, Ma Z, Fu ZR, et al. (2012). Effects of green-keeping treatment on the functional constituents in flower tea of Eucommia ulmoides. Ind. Crop. Prod. 36: 389-394.

Hale AL, Farnham MW, Nzaramba MN and Kimbeng CA (2007). Heterosis for horticultural traits in broccoli. Theor. Appl. Genet. 115: 351-360.

Hsieh CL and Yen GC (2000). Antioxidant actions of du-zhong (Eucommia ulmoides Oliv.) toward oxidative damage in biomolecules. Life Sci. 66: 1387-1400.

Jaikishan I, Rajendrakumar P, Ramesha MS, Viraktamath BC, et al. (2010). Prediction of heterosis for grain yield in rice using'key' informative EST-SSR Markers. Plant Breed. 129: 108-111.

Kopp F, Smart B, Maynard A, Tuskan A, et al. (2002). Predicting within-family variability in juvenile height growth of Salix based upon similarity among parental AFLP fingerprints. Theor. Appl. Genet. 105: 106-112.

Kwan CY, Zhang WB, Deyama T and Nishibe S (2004). Endothelium-dependent vascular relaxation induced by Eucommia ulmoides Oliv. bark extract is mediated by NO and EDHF in small vessels. Naunyn Schmiedebergs Arch. Pharmacol. 369: 206-211.

Lee MK, Kim MJ, Cho SY, Park SA, et al. (2005). Hypoglycemic effect of du-zhong (Eucommia ulmoides Oliv.) leaves in streptozotocin-induced diabetic rats. Diabetes Res. Clin. Pract. 67: 22-28.

Li G and Quiros CF (2001). Sequence-related amplified polymorphism (SRAP), a new marker system based on a simple PCR reaction: its application to mapping and gene tagging in Brassica. Theor. Appl. Genet. 103: 455-461.

Li SW, Zhang ZY, Yu ZS, He CZ, et al. (2008). Correlation between molecular genetic distances among parents and growth traits of progenies in populus. Sci. Silvae Sinicae 44: 150-154.

Li ZQ and Wang ZR (2002). RARD markers used for the hybrid identification and parents choice in Liriodendron. Sci. Silvae Sinicae 38: 169-172.

Manjarrez-Sandoval P, Carter TE, Webb DM and Burton JW (1997). Heterosis in soybean and its prediction by genetic similarity measures. Crop Sci. 37: 1443-1452.

Nakamura T, Nakazawa Y, Onizuka S, Satoh S, et al. (1997). Antimutagenicity of Tochu tea (an aqueous extract of Eucommia ulmoides leaves): 1. The clastogen-suppressing effects of Tochu tea in CHO cells and mice. Mutat. Res. 388: 7-20.

Nakazawa Y, Bamba T, Takeda T, Uefuji H, et al. (2009). Production of Eucommia - rubber from Eucommia ulmoides Oliv. (Hardy Rubber Tree). Plant Biotechnol. 26: 71-79.

Nei M and Li WH (1979). Mathematical model for studying genetic variation in terms of restriction endonucleases. Proc. Natl. Acad. Sci. U. S. A. 76: 5269-5273.

Porebski S, Bailey LG and Baum BR (1997). Modification of a CTAB DNA extraction protocol for plants containing high polysaccharide and polyphenol components. Plant Mol. Biol. Rep. 15: 8-15.

Rohlf FJ (1998). NTSYSpc Numerical Taxonomy and Multivariate Analysis System, Version 2.1. Exeter Software, Setauket.

Takamura C, Hirata T, Yamaguchi Y, Ono M, et al. (2007). Studies on the chemical constituents of green leaves of Eucommia ulmoides Oliv. J. Nat. Med. 61: 220-221.

Vaillancourt RE, Potts BM, Watson M, Volker PW, et al. (1995). Detection and prediction of heterosis in Eucalyptus globulus. For. Genet. 2: 11-19.

Wang DW, Li Y and Li ZQ (2011). Identification of a Male-Specific Amplified Fragment Length Polymorphism (AFLP) and a Sequence Characterized Amplified Region (SCAR) Marker in Eucommia ulmoides Oliv. Int. J. Mol. Sci. 12: $857-864$.

Wei YC, Li ZQ, Li Y and Chang L (2012). Genetic analysis of morphological traits of Eucommia ulmoides Oliv's hybrid offspring. J. NW. A\& F Univ. 40: 137-143.

Wu MQ, Chen SL, Wang MX and Yan SZ (2011). An analysis of the genetic diversity and genetic structure of Eucommia ulmoides using inter-simple sequence repeat (ISSR) markers. Afr. J. Biotechnol. 10: 19505-19513.

Genetics and Molecular Research 13 (3): 4736-4746 (2014) 
Yu CY, Hu SW, Zhao HX, Guo AG, et al. (2005). Genetic distances revealed by morphological characters, isozymes, proteins and RAPD markers and their relationships with hybrid performance in oilseed rape (Brassica napus L.). Theor. Appl. Genet. 110: 511-518.

Zhang BY, Zhang T, Zhang KJ and Dong J (2004). Selection and Breeding of Superior Species of Qingzhong 1-4. J. NW. Fore. Univ. 19: 18-20.

Zhang Q, Zhou ZQ, Yang GP, Xu CG, et al. (1996). Molecular marker heterozygosity and hybrid performance in indica and japonica rice. Theor. Appl. Genet. 93: 1218-1224.

Zhang XQ, Wang XD, Jiang PD, Hua SJ, et al. (2007). Relationship between molecular marker heterozygosity and hybrid performance in intra- and interspecific hybrids of cotton. Plant Breed. 126: 385-391. 